
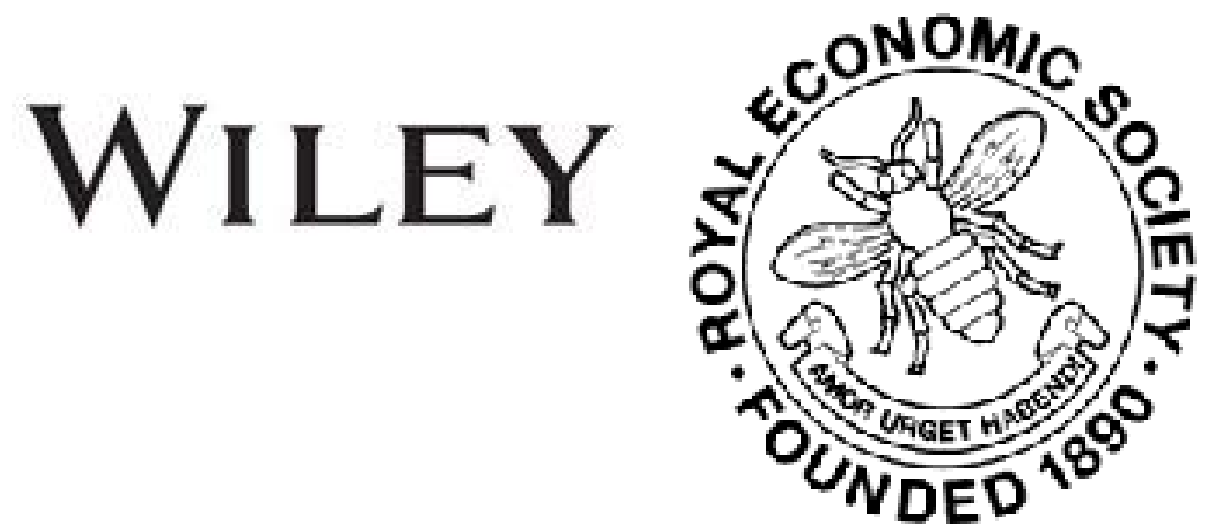

\title{
Review
}

Author(s): L. K. Hyder

Review by: L. K. Hyder

Source: The Economic Journal, Vol. 23, No. 91 (Sep., 1913), pp. 413-414

Published by: Wiley on behalf of the Royal Economic Society

Stable URL: http://www.jstor.org/stable/2222553

Accessed: 27-06-2016 20:27 UTC

Your use of the JSTOR archive indicates your acceptance of the Terms \& Conditions of Use, available at

http://about.jstor.org/terms

JSTOR is a not-for-profit service that helps scholars, researchers, and students discover, use, and build upon a wide range of content in a trusted digital archive. We use information technology and tools to increase productivity and facilitate new forms of scholarship. For more information about JSTOR, please contact support@jstor.org.

Wiley, Royal Economic Society are collaborating with JSTOR to digitize, preserve and extend access to The Economic Journal 
made no less happily in the succeeding chapters; and on every page, or nearly every page, Professor Farnam stirs our flagging notice by some luminous aperçu or sets us thinking by some stimulating comment. We have read of late few books which yield so ample a reward for their perusal.

\section{L. Price}

\section{Die Grundlagen des ökonomischen Liberalismus in der Geschichte der englischen Volkswirtschaft. ${ }^{1}$ By Dr. Hermann Levy. (Jena: Gustav Fischer. 1912. Pp. vii +96. Price M. 3.50.)}

THE title of this book does not readily indicate the scope of its enquiry. The Liberalismus that Prof. Levy has in view is not to be confused with the programme of any political party in the present or with the teachings of the Manchester School of Economists at the beginning of the nineteenth century. On the contrary, the book aims at opening up that period of English history which may be described as a period of industrial preparation and probation, namely, the seventeenth century, with its civil wars and revolutions which transformed State, Church, and Society. It was in these times that the character of the nation formed itself. With the acquisition of civil and political liberty the nation not only shakes off the fetters of the feudal times, but breathes another spirit, and has a new philosophic-economic outlook on life. But for the achievements of this century, Prof. Levy doubts if the way would have been paved for the subsequent economic development of the eighteenth and the nineteenth centuries, which secured to England industrial supremacy when other nations were grappling with problems which she had solved in the struggles of the seventeenth century. Prof. Levy brings out the main facts clearly, and is able to show the bearing, which such liberal measures as free immigration of persecuted foreign Protestants and Jews and the proclamation of tolerance, had on English industrial development.

The book is useful in so far as it directs attention to these questions, but it may be doubted if all the Grundlagen of English economic Liberalismus lie exclusively in this century. By singling it out, he is laying himself open to the same kind of mistake as that against which he specially warns us, namely, the mistake of thinking that the Industrial Revolution in England began with

1 Since the above review was written, this book has been translated into English under the title Economic Liberalism, and published by Messrs. Macmillan, price 4s. $6 d$. net. 
the invention of new machines and appliances. Surely an account to be thoroughly philosophic should take into consideration not only the incidents of a particular period of time, but all the peculiar circumstances of England, and, above all, the character of her people. That character was not wholly formed in the seventeenth century, though some features of it were intensified, as Prof. Levy points out with rather over-emphasis, in the case of the Puritans. However, this part of the book is suggestive and illuminating.

Printed words die hard, and the views of some of the hasty and dogmatic parasites of Adam Smith and his followers receive some notice here-how they transformed a part of CulturLiberalismus into something that was not any more a matter of feeling, a thing that was part and parcel of the individual, but was rather a science, whose laws held true for all times and all stages of development with the rigidity and accuracy of mathematics. What, says the author, is one to think of such men and their so-called science when neo-Mercantilism and Socialism flourish so lustily to-day?

In the concluding portion of his book Prof. Levy shows the England of to-day by way of contrast with the Individualistic England whose beginnings lie in the seventeenth century. The country is swaying away from extreme Individualism to forms of social, collective action, which are making it a Social State; in fact, a Bureaucratic State. Is not the trend of recent social legislation altogether different in its conception of the principles, aims, and objects of the State from that which has hitherto guided it for the last three hundred years? Has not the scope of the economic functions of Government been widened, necessitating the perfection and development of its machinery and bringing into prominence the Official, who is the central figure in the Bureaucratic countries of Europe? On the note of these questions the author concludes. Perhaps he has taken, sometimes, the words of politicians too seriously.

L. K. HYDER

An Economic Interpretation of the Constitution of the United States. By Charles A. Beard, Associate Professor of Politics in Columbia University. (New York: The Macmillan Company, 1913.)

MUCH might be said about this book. For one thing it is an important sign of national and academic movements now stirring in America that a Professor of Politics should essay an 